\title{
Technical expertise: Diagnostic and descaling solution of geothermal waters in arid zone
}

\author{
Anis Elaoud ${ }^{1^{*}}$ and Hamza Ben Amor ${ }^{1,2}$ and Mohamed Ben Amor ${ }^{3}$ \\ 1Research Laboratory of Environmental Science and Technologies, Higher Institute of Sciences and Technology of Environment, Tunisia \\ ${ }^{2}$ University of Carthage, National Institute of Agronomic, Tunisia \\ ${ }^{3}$ Laboratory of Natural Water Treatment, Water Research and Technologies Center, Borj Cedria, Tunisia
}

Received 02 Dec 2017, Accepted 03 Feb 2018, Available online 10 Feb 2018, Vol.6 (Jan/Feb 2018 issue)

\begin{abstract}
In Tunisia, geothermal waters show problems of scaling and clogging of pipes and basins. Several chemicals are the basis of anti-scaling solutions. Our expertise illustrates a simple and inexpensive technical solution by injecting 'STPP' (Sodium tripolyphosphate) at a rate of $0.8 \mathrm{~g} / \mathrm{m}^{3}$.
\end{abstract}

Keywords: Scaling and clogging etc.

\section{Introduction}

Tunisia has a geothermal water potential very important in the south with a flow rate that exceeds $100 \mathrm{~L} / \mathrm{s}$ per structure. This allowed these resources to be exploited to develop the oases and crops of the fifth season. The project has a primordial priority "socio-economic development promoting and strengthening of territory". The support for innovation and research is based on local development process for Mediterranean countries.

This project will be built on valorization of various researches to control and management of irrigation water in arid regions, particularly at oasis and palm groves. It will consist of following topics:

- Geothermal water for preservation of oasis.

- Inhibition of chemical scaling of installation: pipeline, drippers, coolers, basins, etc.

- Use of geothermal water for irrigation, recharge of groundwater and energetic resources.

- Water desalination for agriculture use (use of geothermal water).

- Use of renewable energy for pumping and treatment of water.

- Development of a monitoring system for optimal management of irrigation system.

- Study of socio-economic impact at arid regions.

- Optimization of irrigation technique in consistent with a better quality of water.

*Corresponding author's ORCID ID: 0000-0003-3540-4171

DOI: https://doi.org/10.14741/ijmcr.v6i01.10917

\section{Tunisian partners}

- Technopark of Borj Cedria: CERTE, CRTEn and CBBC.

- Agriculture ministry services: INAT and CRDA

- IRA

\section{The partners will be specialized on}

- Geothermal water: quality and treatment,

- Membrane development (low cost),

- Thermal desalination,

- Irrigation technique,

- Groundwater recharge,

Problematic and diagnostic of the initial state

The southern basin of the Mediterranean countries suffers from water scarcity mostly at desert regions. Indeed, the desert continues to advance due to sand erosion. In Tunisia, to avoid this phenomenon, it is possible to develop these regions by using nonconventional water resources, like geothermal water, which is depth between 1000 and 3000 meters. There are more than 40 deep wells which produced $100 \mathrm{~L} / \mathrm{s}$. This water is used to:

1. Irrigation of oasis of Tozeur, Kebili and El Hamma,

2. Develop a new irrigate parameters and incoming oasis,

3. Improve the socio-economic level of resident, allowing them to develop agriculture with high added value like early produce, geothermic greenhouse and spa pleasure.

4. Several European and Arabic promoters have invested in desert regions and their productivity was increased. 
Unfortunately, there are many difficulties in the exploitation of geothermal water such as clogging pipes, fouling pumps, aerators, screens and other equipment. For instance, a pipeline designed for 30 years are fouled within 3 years. The formation of scales in coolers may require further maintenance, descaling and replacement of equipment.

To overcome these problems we have developed promising methods which prevents water supply through pipeline without formation of precipitate.
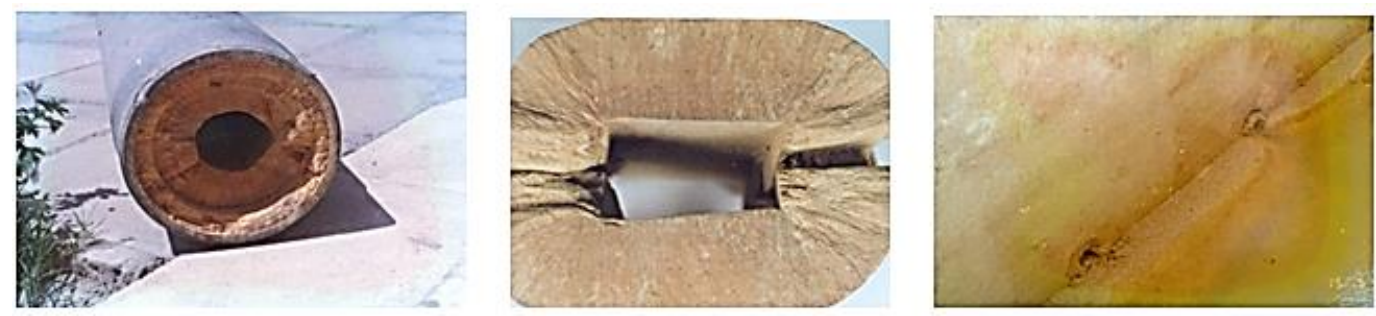

Fig.1 Deposit and scaling

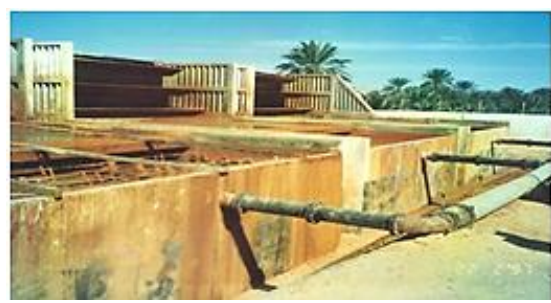

Fig.2 Drilling El Ain Kebili
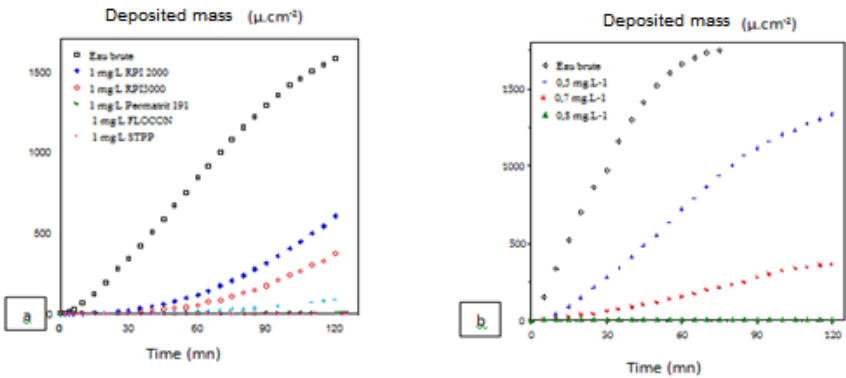

Fig.3 Descaling of geothermal water
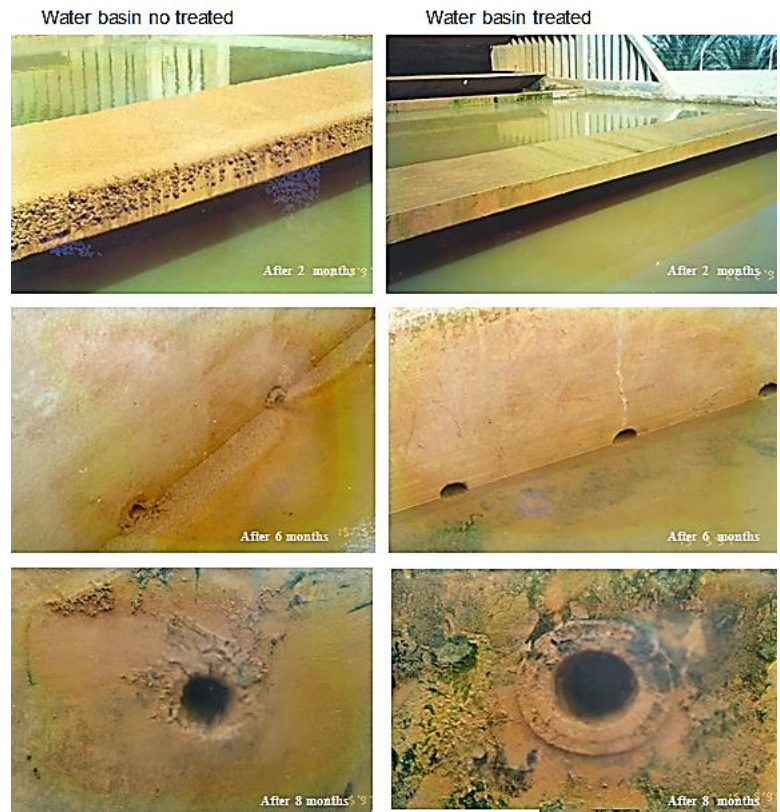

Fig.4 STPP effect on descaling 


\section{Solution of descaling and prevention}

With a very low dose of sodium phosphate (one gram per cubic meter of water), we can stop the clogging of pipes and structures. This allows us to exploit this water without any inconvenience. The figure (Fig 3.a) below show the effect of the different commercial products and also the effect of STPP-Sodium tripolyphosphate- $(1 \mathrm{mg} /$ $\mathrm{L})$. The figure 3.b show the effect of the different dose $\operatorname{STPP}(0.5,07,08 \mathrm{mg} / \mathrm{L})$. We note that the optimal dose is $0.8 \mathrm{mg} / \mathrm{L}$ for descaling and prevention (Fig 4).

\section{Conclusion}

With a very low dose of STPP-Sodium tripolyphosphate$\left(0.8 \mathrm{~g} / \mathrm{m}^{3}\right.$ of water), we can stop the clogging of pipes and structures. This allows us to exploit this water without any inconvenience.

\section{References}

[1]. Massechelein W. J. (1997). Processus unitaires de traitement de l'eau potable, CEBEDOC, France, 1997, p.564.

[2]. Walha K., Ben Amor H., Rosset R. (1997). L'inhibition de l'entartrage par les eaux géothermales du Sud-Tunisien, influence de la température, J. Soc. Chimique de Tunisie Vol IV $-\mathrm{N}^{\circ} 2$

[3]. Walha K., Ben Amor H., Rosset R. (2000). J. Soc. Chimique de Tunisie Vol IV - N8 L'Adoucissement électrochimique procédé de lute contre l'entartrage.

[4]. Ben Amor M., Zgolli D., Tlili M. M., Manzola A. S. (2004). Influence of water hardness, substrate nature and temperature on heterogeneous calcium carbonate nucleation, Desalination 166, 79- 84 